\title{
The Teaching of Geography
}

\section{Professor Alex Darroch}

To cite this article: Professor Alex Darroch (1906) The Teaching of Geography , Scottish Geographical Magazine, 22:9, 484-490, DOI: 10.1080/00369220608733667

To link to this article: http://dx.doi.org/10.1080/00369220608733667

册 Published online: 27 Feb 2008.

Submit your article to this journal 준

III Article views: 5

Q View related articles ¿ 
the antarctic regions properly speaking (of its eighty species of mosses thirteen are also found in the antarctic); its Magellan affinities are naturally very pronounced, yet considering its nearness to Fuegia and the prevailing westerly winds, it is a matter for wonder that more of the South Georgian species are not found there, and that the proportion of endemic species should be so high in respect of mosses, viz. fifty per cent. according to Dr. Cardot's latest determinations. Among its thirteen species of phanerogams are none which are endemic, a fact not a little remarkable considering how, in similarly isolated islands, such as Tristan da Cunha and Gough Island, the endemic species and varieties form a conspicuous element of the flora, while Kerguelen and other islands to the east are also not wanting in this respect. Possibly the relative accessibility of South Georgia to the Magellan Lands accounts for its want of peculiar species, but if this is so the number of endemic mosses does not become easier of comprehension.

The affinities of the flora of the New Zealand group of sonthern islands with that of Fuegia is another extremely striking fact, and one whose explanation is yet far from being satisfactorily found ; but reference must be made to a recent paper of Dr. L. Cockayne's on "A Botanical Excursion during Midwinter to the Southern Islands of New Zealand." (Trans. N.Z. Instit., xxxvi. p. 225).

To a fuller discussion of the relationships of the floras of these southern islands in their possible bearing on the former distribution of land, I hope to return at a later date. In the meantime enough has been said to indicate the nature of the botanical problems a waiting solution in antarctic and sub-antarctic lands, and while future expeditions will naturally choose their routes largely for oceanographical and geographical reasons, there will always be in any land touched at, or for that matter in any sea, sufficient material of botanical interest to be found. The pole-circling islands are more likely to be well explored as the importance of the study of the vast southern oceans begins to attract attention and when the day of simple boyish pole-hunts is over, as will surely soon be the case.

\section{THE TEACHING OF GEOGRAPHY.}

By Professor Alex. Darroch.

I HAVE been asked to say a few introductory words in reference to the aims and intentions of the promoters of the exhibition which opens to-night across the way at the Outlook Tower. Before doing so, I think we ought to thank both the organisers of the exhibition, and also those who have forwarded exhibits, for the opportunity afforded us of becoming acquainted with what must be done if we are to make the Geography teaching of our schools real, concrete, and truly educative. For the questions as to the proper place of Geography teaching in schools, and

1 An address delivered at the opening of the Geographical Exhibition in Edinburgh on July 6 . 
especially in our Secondary schools and in our Universities, and of the right methods of imparting this branch of knowledge, are receiving at the present day greater and greater attention from all concerned in the work of Education, and an exhibition such as this can do much to enable us to return right answers to these two problems. As instances of the importance attached to this subject, I may mention that the teaching of Geography now forms an important part of the new commercial course recently inaugurated in the Secondary schools of this country; and already we have signs that more rational and educative methods of teaching the subject are becoming prevalent in the schools. Again, to take another instance, it may be noted that under the new scheme for the Training of Teachers it is required of every teacher of English in our Intermediate and Secondary schools that he must produce evidence of having attended a course of instruction in Geography, and further there is provision made for the training of special teachers of the subject, and it is expected that at least in the larger and more important of our schools one member of the staff should have this special qualification, and so be employed in the teaching of the subject in its more advanced stages. Lastly, there has been a movement to establish a Chair of Geography in the University of Edinburgh, and to include the subject as one which may form part of a degree course. In furtherance of this movement, the University Court, in conjunction with the Royal Scottish Geographical Society and the Chamber of Commerce of Edinburgh and Leith, and other bodies interested in the subject, appealed some time ago for subscriptions in order that this object might be attained, and although a considerable sum has been raised, yet further subscriptions are required in order to attain the end in view, but it is hoped that in the immediate future a sufficient sum will be obtained, so that steps may be taken in the ensuing winter to establish, if possible, a Chair in the subject within the University.

In this connection I may be allowed to say a word or two about the strange apathy and neglect of the scientific study of Geography in this country.

In America, in Germany, in other continental countries, the subject is thoroughly studied and in a scientific manner, and in these countries it is recognised that the study of Geography is not only valuable as an instrument of intellectual culture and of mental discipline, but is also valuable from the point of view of the commercial and industrial progress of the nation, and is, further, of the utmost importance to those to whom is entrusted the defence of the country.

Here in our own country, principally because there is current a wrong conception of the nature of Geography, and a narrow impression of the extent and complexity of the subject, nothing has as yet been done to put Geography in its place as a subject eminently suited to be admitted into the University curriculum. The University of Edinburgh was the first of our Scottish Universities to recognise the importance of the subject, and to take steps, in spite of opposition from quarters where help might have been expected, to place it in its proper position, and I sincerely trust that the citizens of Edinburgh and Leith will see voL. XXII. 
that the efforts of the University and of the Royal Scottish Geographical Society may not be allowed to fail ; and that the funds necessary for the establishment of the desired Chair may soon be in their hands.

Various causes have been at work to produce the renewed interest in the teaching of Geography thus manifested. In the first place, it has been clearly realised that the older methods of teaching the subject, which I am sorry to say in some cases still prevail, crammed the memory of the child with a host of more or less uninteresting facts, and did nothing either to feed or to cultivate the imagination, or to train the reason of the pupil. This is true whether the method relied on be mere book knowledge, or whether the teaching be supplemented by the use of the ordinary maps. The latter method was and is certainly an improvement on the former, but yet mere map understanding is not sufficient for the complete comprehension of geographical facts and their inter-relations with one another. Much less is it so if we endeavour, as we ought, to make our pupils realise that the geographical facts of a district condition, and to some extent are conditioned, by the more important natural and social phenomena whose exact study belongs to other but related sciences. For it is only by keeping this latter point of view ever in mind that our geographical teaching can be made real and living to the child. Again, it is being slowly realised that any kind of geographical teaching which trains the reason of the pupil to the perception of the causal inter-relation between physical fact and physical fact is the best medium by which to introduce the youthful mind to the study of the Natural Sciences, and hence it has been well said that Geography teaching may be made the gateway to the teaching of Science; for the subject of Geography, of all school subjects, if rightly taught, may enable a child to realise that the world in which he lives is not a mere sum of facts, but an inter-related system, a cosmos, in which fact is related to fact, and conditions and is conditioned by the nature of the whole. In this connection I may for a moment allude to an opinion held strongly by many educationalists of the present day. They contend that the exact sciences, such as Physics and Chemistry, should be preceded by a course of study having for its object the training of the pupil to perceive the larger and more obvious causal inter-relations existing between the various parts of the Universe; and they further maintain that if we begin to endeavour to lead a young pupil to select out and to endeavour to understand the more minute and less obvious causal interrelations, before he has undergone a training in the discrimination of the first-named set of relations, then our method is educationally erroneous, and is one not likely to produce the best results in training the pupil in the methods of Science and in the formation of the so-called. scientific habit of mind. For in the study of Physical Geography and the allied branches of knowledge, the facts to be observed and the interrelations to be discerned are easily separated out from the whole of which they form a part, and can be made readily obvious to minds incapable, through immaturity, of understanding the more abstract and intricate system of causes with which sciences such as Chemistry and Physics 
deal. However that may be, all are agreed that the study of Geography in the widest acceptance of the term is one of the best instruments for extending the horizon of the pupil, for the cultivating of his imagination, and for training him to reason and to realise the Universe as a system. But a knowledge of Geography is not merely valuable as a preliminary to the more thorough and the more accurate study of the Natural Sciences, it is in many cases necessary for the right understanding of historical facts, and for the thorough comprehension of the history of our own and of other countries. A moment's reflection will enable any one to realise that geographical conditions have largely determined historical change in the past, and that the historical conditions existing at the present can be made completely intelligible only through the prior understanding of the geographical relations. Again, and above all, a full knowledge of geographical facts is necessary for the right understanding of the economic and commercial conditions of our own and other countries. For the localisation of a people and the distribution of their industries within any one country and throughout the world generally can be made thoroughly intelligible only when our Geography teaching has clearly realised this as its ultimate aim, and when the knowledge has been imparted to the pupil according to a sound method. As the final result of our teaching of Geography, we should have made our pupils realise not merely that a certain city or town is placed here or there, but why this is so; not merely that it has such and such industries, but why these industries are located here and not elsewhere ; and lastly, they must understand the use and function the particular city plays in the economic and social life of the nation and of the world generally. Only in so far as we have done this can we be said to have taught the subject at all. Further, while the economic and commercial aspect of the subject is so important for a country such as ours, from the narrow utilitarian point of view, that the knowledge and training is necessary for all those who intend in after-life to enter upon a commercial career, yet it is also important from the fact that it is only by a method which endeavours to attain the end of showing the value of Geography for the understanding and interpretation of the economic and social life of a people that we can really educate the child and train his reason. Now the aim of this exhibition is to make us all realise that the teaching of Geography is necessary for the true interpretation of natural and social phenomena; that without the preliminary training which Geography teaching gives, our efforts at imparting Natural Science will be more or less ineffective ; that without a correct knowledge of the facts of Geography, our historical interpretation of the past and our understanding of the historical associations of our own times can never be complete; and that the economic and social life of a people is unintelligible except through a knowledge of the physical environment which everywhere and in all times conditions the growth and distribution of a people and the localisation of their industries. Lastly, and above all, the aim of the organisers is to endeavour to bring home to us the unity and inter-connection of all knowledge, to make us realise that Geography teaching is not concerned with a particular set of facts and a particular system of causes, but that 
many systems of facts and their inter-relations must be understood if we are to understand the nature of the social whole.

The second, and perhaps the more important, object of the exhibition is to enable us to obtain some insight into a true and sound method of imparting geographical knowledge, and to give us some insight into methods of arousing, maintaining, and sustaining the interest of our pupils in this particular subject, so that as our final aim we may enable them in after-life to comprehend intelligently the social and economic world in which as men and women they will have to take their place and perform their appropriate functions. Now the best method of imparting geographical knowledge is to go direct to Nature and learn from direct observation the causal interaction of physical fact to physical fact, and how the natural and physical features of a country or district determine the social and economic life of the people. This was the method of Rousseau; still more so was it the method of that much greater educationalist, Pestalozzi, in the teaching of Geography. The cardinal principle of the educational method of Pestalozzi was that the symbol should never be given to the child until he had comprehended the thing signified by the symbol, and we are told that once when his own child used a term without a knowledge of the thing signified by it, he wept from sorrow at finding such an example of educational depravity in his own offspring. In his teaching of Geography, Pestalozzi carried out thoroughly the maxim of presenting the symbol only after the thing itself was comprehended. In the once famous school at Burgdorf the children, along with their teacher, explored the country in the neighbourhood of the school, collecting clay in baskets from the river-banks, and on their return modelled out day by day what they had learned of the physical nature of their environment, and of the inter-connection of physical feature to physical feature. Only after this had been thoroughly comprehended from the clay model was a flat map introduced and the relation of model to map explained. In our present-day teaching of Geography this method of going direct to Nature should be employed wherever possible, and especially in the earlier stages, and any other method must be judged good or bad according as it approximates or falls short of the direct method.

But under the altered conditions of our time, and especially in our large towns, the method of going direct to Nature can be followed only to a limited extent, and further the method has limitations in itself which makes its consistent use inapplicable under existing conditions, for it is obvious that the direct method is always limited by the narrow range of the child's environment. Again, the best method of teaching here, as in so many other subjects, cannot be employed in its entirety even if it were possible, on account of the limited time in which the knowledge must be imparted. Hence the direct method must be supplemented by others, and all these subsidiary methods must have for their aim the endeavour to. make Geography a real, a concrete, and a living subject of instruction. If the Geography teaching of our schools has only for its results the memorising of lists of names extracted from a book or gleaned from the unintelligent and premature use of a map, then what- 
ever we may be doing we are not educating the child. Nay, more, by such methods we not only kill the child's present interest in the subject, but also fail to foster any future or later interest; and in many cases such teaching tends to make the child grow up dull, stupid, and unimaginative, and with reason dormant about the world in which he lives.

It would ill become me, however, at this time and in this place to inflict upon you a lecture on the method of teaching Geography, but before closing there are one or two principles to which I have alluded already, and which this exhibition is meant to illustrate, that I should like to draw attention to. In the first place, the exhibition furnishes many instances of the practical application of the principle that, wherever possible, whether in the teaching of Physical Geography, of Political or Commercial Geography, or the interconnection of these facts with the social and economic facts, we must base our teaching upon what is already known to the child and within his comprehension. Then upon this as a basis we must proceed to form a concrete and living idea of $\mathrm{tl} e$ district or region as a whole. But we must also remember that the mese picturing of a district or of a country is not sufficient; the child at a later stage must be trained to employ his reason in the perception of the causal inter-relations at work. Now, one particular section of the exhibition has for its aim to show how by means of models and diagrans such a concrete picture may be formed in the mind of the child, and how we may train his reason in the perception of the causal inter-relations at work. Another principle, of which the exhibition gives concrete illustration, is that the symbol should follow and not precede the thing signified, and that in particular the understanding and comprehension of a map should be based and follow upon the prior understanding of the reality of which the map is merely a diagrammatic illustration.

But if we limited our teaching of Geography to the mere understanding of the child's own district and of his own country; if our only aim were to make him realise how many factors have to be taken into account in the thorough interpretation of any one region, then we should not attain the highest result, and we should fail to realise all that we should endeavour to do in our Geography teaching. In addition to this, we must further endeavour to lead our pupils to a knowledge and understanding-imperfect it may be-of the world as a whole, and of the relation, position, and place of his own country to the whole. Now this is a second aim of the present exhibition. It endeavours to show how, by the use of models of pictures, of lantern-slides, and other concrete means we may widen the intellectual horizon of the child; how we may extend his range of vision and cultivate his imagination; and how we may deepen and broaden his sympathies.

There are other aims on which, had time permitted me, I might have $\mathrm{d}$ welt, but I shall call attention briefly to one other object which is sought to be attained by the present exhibition. It is not sufficient that we should know how to lead our pupil to understand and interpret his immediate physical environment, nor is it sufficient to lnow how to make him best realise the place and function of his own country on this 
terrestrial globe; we must further endeavour to make him comprehend the nature of the Universe as a whole, and how this planet on which he lives is related to the solar system of which it forms a part, and to the other systems which the starry heavens reveal to our gaze. We may thus lead him to understand the vastness, the complexity, the grandeur, and the mystery of this Universe in which man at times seems to play but a poor and sorry part.

\section{A LITTLE.KNOWN RUSSIAN PEOPLE: THE.SETUKESED OR ESTHS OF PSKOV.}

By V. Dingelstedt, Corresponding Member of the Royal Scottish Geographical Society.

THE ethnical maps of Russia are as yet far from being accurate; their small scale does not usually permit of the indication of minute, but not unimportant details, and besides, there is an obvious tendency to consider as ethnically Russian all those parts of this immense Empire, in which orthodoxy and obligatory Russian usages have been officially introduced in school and church. Many of the readers of this Magazine have probably never even heard mentioned the name of the small race indicated at the head of this paper, and yet it occupies a distinct territory of about 4500 square miles, and its peculiarities have been considered by the Imperial Russian Geographical Society as sufficiently interesting for them to instruct one of their members (the Rev. J. Gurt) to undertake under their auspices the study of the manners, language and literature of this people. In the first part of vol. xli. of Isvestia we find an interesting account of this study, the summary of which may perhaps interest our readers. It is indeed very probable that now, when Russia seems about to enter a constitutional path, with greater respect for the distinct ethnical elements comprising it, we shall learn that this Empire is far less homogeneous than we have been inclined to think till now, thanks to the prevalent policy of denationalisation.

The Esths or Esthonians, often mentioned lately in connection with the revolutionary movement in Russia, inbabit a country which extends south of the Gulf of Finland, as far as the rivers Pimja (Piusajogi) and Vo (Wanjögi), tributaries of the lake of Pskov. They at one time (1346$1561)$ belonged to Teutonic knights, and are now separated into two distinct races: the conquerors-a mixture of Germans, Swedes, and Russians-called Esthlanders, and the conquered original possessors of the soil, which belong to the Finnish race and are called Esths or Esthonians. The eastern branch of the Esths on the Pimja and Vo rivers, converted to Greek orthodoxy, are known under the name of Setukosy (Setukesed), and their country (4500 square miles) is called Setukesia by Russians and Setumaa by the natives.

According to the census of 1897 , there are 16,576 Setukesed (8158 males and 8413 females.) The country has no particular attractions, and 